\title{
Religious Hermeneutic as a Means of Sustaining Peace
}

\author{
Akintayo Sunday Olayinka ${ }^{1}$ \\ ${ }^{1}$ Affiliation not available
}

November 4, 2022

\begin{abstract}
This paper presents the roles the interpretations of religion (or texts) and understanding of religion play in the sustainability of peace among the Yorùbá people of southwest Nigeria. The Yorùbá's way of interacting and practising religion has remained moderately amiable over the last two centuries when compared with other communities in Nigeria. With attention on Yorùbá Christians and Muslims, this author examines some specific religious concepts and values that have been useful in guiding the two religions to retain their peace or return to dialogue table to refrain from violence and keep the peace. The paper argues that the interpretations of some religious terms and values among the Yorùbá enhance their pursuance of peace.
\end{abstract}

Please note: The bulk of this article is taken from chapter 8 of the author's doctoral dissertation with a few amendments to suit this journal.

Keyword: Peace - Conflict - Resolution, Christianity, Islam, Culture, Yorùbá

\section{Introduction}

This paper attempts to examine the role the interpretations given religious terms and values play in the community tolerance. If people of the same religion behave differently in different parts of a nation or the globe, the cause of the differences could be the cultural differences within each host community where the religion is practised and/or the interpretations given the various religious terms in each location among other factors. The author, thus asks the question: in what way does the interpretations given to religious concepts or values help in the pursuance of peacefulness in a community?

Hermeneutics has to do with interpretation (of concepts). Put in another way, it is 'the study of the methodological principles of interpretation [often used for the Bible] ... a method or principle of interpretation', (Merriam-Webster. n.d.). It is taken from the root word herméneutikos, (Merriam-Webster. n.d.). Hermeneutics, therefore, is used in this paper synonymously with interpretation while considering the cultural influences of such interpretations on the religious terms and values.

This paper uses interviews and focus group as the method for gathering the data and thick description to analyse the findings. The discourse is around the findings from 72 participants in three focus group discussions and 27 interviews among the Yorùbá of southwest Nigeria.[1] 


\section{2. $\quad$ Religion and Socio-Cultural Values: The Meeting Point}

An average Yorùbá cherishes religious consciousness and the concept of eternal judgement. They socialize through celebrations such as weddings, baby naming, birthday parties, new house opening, funerals and other areas considered an essential part of living that calls for rejoicing. They interact through family connection and community meeting. Muslim neighbours, for instance, attended p's wedding ceremony (FGD3) and joined in the wedding reception, where people ate, drank, and danced to the provided music. Furthermore, a Christian university student tenant by name Ronke (FGD1a) expresses how her Muslim landlord (at a university student private accommodation) often requested prayer from herself, while going to church or Christian student fellowship meetings. This is a common practice among the Yorùbá, requesting prayers from one another. Muslims participated in the cooking during the graduation ceremony of Sàngó from the seminary as a trained Christian minister, and Wlé travelled from southwest to northern Nigeria for the wedding of a former colleague's daughter, even though they do not practise the same religion. Both Christians and Muslims were present at the funeral service of an 81-year-old Christian clergyman in Ògbómoso. While the interactions are not limited to these alone, these are some of the social-religious occasions where members of the two religions meet for positive engagements, in addition to their daily encounters at work and in the neighbourhood.

Can similar good relations be found elsewhere? In the Senegalese context, UguccioniI reports how some Muslim leaders requested for prayer from the Christian priest:

Relations between Christian and Muslim religious authorities are also very friendly. Father Flavio cites, among many, two episodes that he considers key: 'Some time ago a boy came to tell me that the imam of the neighborhood wanted to see me. When I came to him I discovered that he had been ill for a week: he had called me because he wanted us to pray together. Another imam, two years ago, when his third son was born, asked me for the courtesy of reaching him because he wanted me to bless the newborn'. (UguccioniI, 2018).

This shows the level of trust that people can have for one another in times of need. With reference to the 81year-old's funeral previously mentioned, the deceased was a Christian minister from a Muslim background. The author interviewed two women cousins of the deceased (Bolanle and Taibatu FI). The Taibatu, a woman had her hijab on while the Christian woman, Bolanle, dressed in the Yorùbá woman attire with a neck and headscarf both walking towards the church for the funeral. Christians and Muslims were present at the funeral. The Muslim men who were not willing to remove their caps as the Christian Yorùbá men do at worship sat in the company of other worshippers and sympathisers under the canopy outside the church building, as the inside hall was full. The Muslim women present wore the hijab and sat throughout the service. One can see that the Yorùbá see beyond their religious differences and celebrate with one another, doing so without necessarily compromising their individual faith. The Yorùbá describe their coming together for social celebrations as aaremise, a social concept rooted in the Yorùbá culture. Social interaction is a binding force among many Yorùbá as well as among the peaceful societies (PS). What is the basis of this unity?

\section{Kidà (Kaida or Kyídà): Religious Hermeneutic and Leadership}

Further to social interaction that unite the Yoruba is their interpretation of certain concepts. Some of the abilities of a religious community to sustain a harmonious society lie in the clerics' values, teachings, the interpretation of their scripture vis a vis the influence on their community. These also determine the level of freedom and tolerance their followers will exhibit. The clerics and the contents of their messages/sermons are crucial to the harmony among the people they lead. Some relevant examples from this study data are:

the incidents at the University of Ibadan mosque versus the evangelical female student, 
interpretation or religious values and leadership,

The Yorùbá leadership had been able to largely manage those incidents, even the Spetrí conflict that dragged for years and hoping the ongoing Ilorin hijab controversy would be resolved based on the Yorùbá's history and skills in handling such crises.

A University of Ibadan (UI) Christian student once disrupted the University Mosque service, the incidence that could have led to serious violence, but the Mosque and university leaderships managed the situation, (Adesina and Gbenro, 2010), which was covered by many Nigerian newspapers. Wole also reported this incidence in the focus group meeting (FGD3). Prior to that crisis, though not connected, M.K.O Abiola (a Muslim businessman and later a Nigerian president elect) had made a demand in 1985 that the University Catholic Chapel Christian's Cross statue erected in 1954 in the vicinity of the University Mosque be demolished. The argument he put forward was that the Cross statute was visible from the newly built mosque in the University. This led to conflict with no violence and a compromise was reached to build a concrete screen to block the view of the cross from the mosque premises (Peel, 2016, p. 147). Peel adds:

When the dispute was eventually settled, there was a great sense of relief at having pulled back from the brink of something very nasty and un-Yorùbá - the more because of the intermittent outbreaks of serious religious violence that were by then occurring widely in Northern Nigeria. (p. 148).

Abiola was well known as a responsible philanthropist and related well with people of all religions - home and abroad but his proposal about the UI Cross almost marred his reputation. So, Yorùbá leaders have been given credit for the way in which they have managed disputes, with the exclusion of the contemporary politicians' related crises, where it is claimed they have brought untold hardship to their people through corruption. The local leadership and influence of the religious moderates[2] on the aggressive[s] in each religious community determine the prevailing disposition of the society towards peace.

Furthermore, the contents of the teachings of clerics are relevant to community unity bearing in mind the thick description (Freeman, 2014; Geertz, 1994; Buchanan, 2018) relevant here. Could the contents and interpretation (hermeneutics) provided by a religious leader contribute to the followers' tolerance? The author brings in focus an example to illustrate this point. Lateef attributes the reasons for Muslim men wearing their hats in worship, while the Yorùbá Christian removing their hats as part of the understanding they both have displayed over the years (FI). This understanding and respect have helped their togetherness as they to attend one another's social and religious functions over the years. Lateef claims to have attended his Christian brother's programmes and informed him that he would not move close enough to be mandated to remove his cap as, being a Muslim, he is required to wear a hat during worship. He made his belief in the freedom of religion clear, citing the Qur'an 2:256 ('There is no compulsion in religion') to reinforce his point (FI). Both Wlé and Maku in different towns and locations also cite this Qur'anic text in their narratives. The religious hermeneutical style adopted to form religious principle play significant roles in the understanding of the followers and their attitude or practices of religion. This in turn affects the contents of the sermons, teaching and contribute to the community's tolerance and the other way around.

With reference to UguccioniI in Senegal, open-mindedness and the proper teaching of cherished values are deemed important to maintaining a harmonious community:

It is important that there are people in the community who are open-minded, capable of educating others with concrete gestures. Our mayor, for example, participates in Muslim activities, but is also present in Christian activities. (UguccioniI, 2018).

Thus, Lateef's knowledge of his own beliefs and the need to navigate those of others concerning his use of a cap in worship, without causing offence, help him to maintain reasonable boundaries, keeping the peace with his Christian brother and remaining a committed Muslim, whilst his brother (a convert from Islam) remains a devout Christian minister. This mirrors the situation in Senegal, (Senegal-n.a. 2009; Wisconsin, 2009) where mutual knowledge and respect is identified as crucial to the continued unity and peaceful relations 
among the majority of Sufi Muslims and the minority Roman Catholic Christians.

\subsection{Kyidà}

Why are there peaceful Christian - Muslim communities in some places like among the Yorùbá whereas it is difficult to maintain harmony among the two religions' adherents in some other places like Kaduna in northern Nigeria? In Kaduna, many Christians and Muslims live separately due to the frequency of violence and religiously motivated conflicts (Okoye, 2014; Diji, 2012; Kazah-Toure, 2003). The clue to the harmony among the Yorùbá is partly discussed by scholars as illustrated in the bi theory (Akinjogbin, 1966; Lateju, 2012). Are there other clues to this harmony? Thick description qualitative approach will be relevant to explore this further.

Lateef in this study suggests the idea of Kyidà in Islam, when he tried to explain the tolerance displayed in the practice of Islamic Law (Shari'ah) by the Yorùbá Muslims, who remain committed friends of the non-Muslim Yorùbá, especially the Christians. Kyidà is pronounced differently as Kidà or Kyídà according to Taiwo (2020), while Lateef claims this is known only among the Yorùbá Muslims who study Arabic.

Regarding this idea, Lateef was asked why Muslims emphasize the Shari'ah and halal, when there are equivalent principles such as '[A]n eye for an eye' (Deuteronomy 19:21, Leviticus 24:20) and the dietary laws (Exodus 20:31, Leviticus 19:26) in the Bible. Lateef argues that the use of the Islamic shari'ah is necessary to deserve the appropriate rewards from Allah. According to Lateef:

You cannot see all the things that shari'ah contains in other books, but you can see the similarities. Take, for instance, shari'ah allows a Muslim to marry up to four wives. Can you find that in the Bible? [...] That is why Muslims will say: let us use the shari'ah, (FI).

Lateef's comments sound dogmatic because there are polygynists in the Bible, albeit the practice is not legislated or recommended for Christians. There are polygynists out of circumstance, as in the cases of Abraham, Elkanah, David, and even Solomon, (New-King-James-Version, 2006).[3] Zachariah (Luke 1) remains a monogynist, despite not having a child until his old age. The Yorùbá were known to practise polygyny before the arrival of Islam and Christianity and many still practice the union, hence why is polygyny a unique Islamic practice; a question Lateef was unable to answer satisfactorily?

A further elaboration is needed for a thick description of peace among the Yorùbá in the context of family union (marriage, in-laws) and neighborhood. Lateef's responses prompted a question concerning the variety of Shari'ah practices in different parts of Nigeria.

'Which Shari'ah are you talking about as there are broad materials and teachings in this area?' Lateef replied:

There is no book called shari'ah. Shari'ah is extracted from the Qur'an and the Hadith. That is the sayings and actions of the Prophet. From there we derive shari'ah. How the Prophet lived $[\ldots]$ to live according to the prophetic rules [...] Muslims believe that if they follow that, they are practising their religion and they will be rewarded. That aspect of the reward cannot be underestimated when it comes to shari'ah.

This response led to another question: since the Shari'ah is not codified, can Islam highlight the sections found in other religions or traditions, thereby socializing with other people, and mentioning the Shari'ah only when the practice is uniquely Islamic? There is no convincing evidence that polygyny and dietary rules (halal) are uniquely Islamic in a social, religious, or African context; and the practice of the Shari'ah varies across Nigeria.

Yorùbá Muslim women ride on motorcycles with men who are not members of their family or as a form of commercial transport, whilst this is forbidden in some Shari'ah promoting states in northern Nigeria, such 
as Zamfara. Lateef's reply was:

It is very simple; you know we have the sources of Islamic shari'ah [... ] We may see different places approaching shari'ah differently based on their level of knowledge and level of the permissibility of practising that law. In Iwo, [...] If we want to practise shari'ah, women will not be using a motorcycle because the body of a woman ought not to touch a man who is not a member of her family. [paraphrased]

According to Lateef, the separation of genders in school is also based on morality. Feyisetan \& Pebley have suggested virginity at marriage as part of the valued Yorùbá culture (1989), as the prevention of premarital sex cherished among the three groups: Christians, Muslims, and the indigenous people alike. This prompts another question, why Lateef would not use the term 'morals' to describe this reasoning, as taught in the Yorùbá indigenous religion, culture and Christianity, rather than the Shari'ah. Lateef's reply was 'the reward', saying that, 'the issue of reward is the main thing [...] Allah promises to reward those who practice the Shari'ah'.

Another tradition that the author considers relevant to unite is the Muslims' hijab, Christian women's head gear and the Yorùbá host gélé and iborún; but the opposite is the case, dividing rather than uniting in some places. The women head gear and neck scarf are indigenous to the Yorùbá while the three religions had lived harmoniously for centuries without complaints until the political elites opened their eyes that the three headscarf styles are different rather than similar. The politicians gave the people the forbidden fruit from the centre of the Eden Garden again, (Genesis 3), so they now observe and reason differently. The interpretation given religious concepts (like the hijab) has a great influence on the recipients' disposition to tolerance and vice versa.

The use of the term 'Shari'ah' with a political undertone, notably, as a political election campaign promise to be fulfilled seems to segregate the citizens who have similar (head gear and neck scarf) practices. The citizens did not mind the hijab on their Muslims women neighbours in the market, house, community, and within their family until the politicians began to enforce it in private premises like the Christian established schools. This could be interpreted as an Islamization (Tayob 2021) process. Places like Shaki, Spetrí, Ejigbo, Iwo and Ilorin are examples with hijab controverses. It was gathered in 2016 in an interview (FI) that the Ejigbo Baptist High School Ejigbo Osun State Nigeria hijab conflict was presented in court and the Christian school won the case to retain their school ethos and forbid the use of Islamic hijab while in the school. However, new cases have come up, as recently reported in Ilorin Kwara State in 2021 where the court within the state and the sitting governor insisted on the wearing of the hijab in the Christian established school in contrary to the Ejigbo court verdict. A comparison of the hijab cases among the Yorùbá may help in the future final settlement of the conflict.

Also, the three religions among the Yorùbá fast for religious purposes. Each officially teaches sexual purity such as discouraging extramarital sexual unions and premarital sex. There are specifications for acceptable food and cleansing among the Yorùbá and the Judeo-Christian people, Kosher in Judaism, and halal in Islam. All the three religions officially practice heterosexuality.

Bringing the study closer to practice religion without hurting others, Lateef describes the Shari'ah practice among the Yorùbá Muslims as Kidà, that is the rule of the practice of the Shari'ah as far as possible until there is an opportunity to practise it in a fuller form. In his own words: 'Kidà is a rule for practising the shari'ah at some levels and developing as the people have better opportunities to involve more aspects of the Law. So, not many communities practise a full shari'ah.' Lateef contemplates a stricter practice that must be peaceful and not offensive to non-Muslims. Lateef's description of the practice of a full Shari'ah among the Yorùbá implies that more could be on the way, and what that will entail is not clear yet. This is a question that only time can answer because the Yorùbá currently practise the Shari'ah under a rule Lateef described as Kid̀̀, which is the Shari'ah that the situation allows. 


\subsection{The Yorùbá Islamic Kidà (Qaidah)}

Kidà needs a thick description in the context of the Yorùbá practice of Islam. Qaaidah or Kaida pronounced Kidà locally is derived from the Arabic word qai'dah or q'd@ qaeida, which literally means a basis, base, regulation, rule, or norm as an adjective, (Arabic-English-Dictionary), contrary to its use to describe the 'Al-Qaeda terrorist group' (Hellmich) discussed among scholars and the media in the last two decades. The Yorùbá alphabets do not have the letter $\mathrm{q}$, hence letter $\mathrm{k}$ is used in the transliteration of the q in qai'dah. In the context of this discourse, it is al-qai'dah muamalat, meaning the rule of social life. Muamalat is described as:

Dealings. Refers to commercial and civil acts or dealings under Islamic law. Islamic law divides all legal acts into either ibadat ormuamalat. Ibadat are acts of ritual worship such as prayer or fasting, and muamalat are acts involving interaction and exchange among people such as sales and sureties. The distinction is important because the principle in all matters involving ibadat is that they are not susceptible to innovations or change (ittiba). In muamalat, however, there is considerably more room to develop and change the law to facilitate human interaction and promote justice. There is disagreement among Muslim jurists on whether certain legal acts, such as marriage or divorce, fall under the category of muamalat or ibadat. ('Muamalat: Oxford Islamic Studies Online,')

The rule of muamalat can further be explored through darar, meaning out of necessity, the situation that makes some actions permissible, mostly on social grounds. Darar within Islamic jurisprudence is described as:

$[\mathrm{L}]$ egal term [...a a]s an example, during illness, fasting could cause harm, so some schools of law allow an exemption from prescribed fasting during illness. In marriage, darar may be grounds for divorce. For instance, traditional Maliki jurisprudence granted a wife the right to divorce if her husband did not treat her and her co-wives equally or if the husband married a second wife. (Oxford-Islamic-Studies-Online, n.d.)

Some necessities (darar) warranting some rules of social life - is locally called 'doruuri' (or sometimes wrongly pronounced laluri) among the Yorùbá according to Lateef. Kidà in the Yorùbá context became grounds for tolerance such as: the social obligation to render help to people in need like picking up women by a male motorcyclist. This rendering of help or for a commercial purpose as a means of transportation is acceptable among many Yorùbá Muslims but prohibited by some northern Nigerian Muslims.

Another example relevant to Al-Qaidah-Muamalat-Darar (Q-M-D) is the Qi'bla, the direction to face during the Muslim daily prayer (salat) '(toward the Kaaba in Mecca), or a prayer wall in the mosque into which the mihrab (niche) is set, indicating the direction of prayer.' (Oxford Islamic-Studies-Online, n.d.). The direction to face for prayer while travelling in an aeroplane or while in the North Pole is not very certain (except the aeroplane is travelling in the direction of Mecca). Hence Muslims freely make their choices on such occasions. There are also reports of Muslims faced with difficulties of choice of acceptable food (halal) in Muslim minority communities. In such a situation, they had to make informed decision about the available alternatives.

Some Yorùbá Muslims seem to have adopted and extended Q-M-D rule (al-qai'dah-muamalat-darar) on a social basis to render help and show love to their neighbours, Muslims, and non-Muslims alike. In his work on 'The case for secularity in Islam,' Mavani, writes:

First, during Prophet Muhammad's time, at least in theory, religion and state were indivisible; in practice, however, there was an explicit separation between ritual acts of worship ('ibadat) and creed('aqidah), on the one hand, and human interrelations(mu'amalat), on the other. The former are constant, immutable, essential, and trans-historical, whereas the latter consists of rules of conduct and behavior that are open to public negotiation in a space that accommodates civic pluralism. (Mavani, 2011, p. 35).[4] 
Mavani further adds 'thereby suggesting that non-ritual acts are subject to continual elaboration and evolution,' (Mavani, 2011, p. 34). In his own words, Mavani suggests:

A distinction ... between religion's moral authority, ... and the state's coercive power. Given that religious faith and conviction are matters of individual choice, as specified by an unconditional Qur'anic verse on the freedom of religion and conscience, [his footnote 4, Qur'an 2:256] both domains must be separated so that each person can choose his/her own religion and with the right intention(niyyah). This separation is necessary because every act in Islam is morally evaluated on the basis of its underlying intention, which suggests the primacy of moral intent. (Mavani, 2011, p. 35).[5]

The Yorùbá in this study utilize the idea of muamalat to explore human interaction at the social level to accommodate their non-Muslim neighbours. Taking this further in other cultures, Mavani suggests:

The Shari'ah must be acknowledged as the normative, immutable, and the ideal, whereas fiqh is no more than a fallible, human approximation of the Shari'ah that needs to be interrogated critically on an ongoing basis so that it can be corrected and revised in accord with changing times, contexts, circumstances, and customs. Moreover, this approach would probably enable one to create a space for secularity within the Islamic tradition. (Mavani, 2011, p. 35).

In a study, Hills traced the tolerance among the Senegalese Sufis to pluralism rather than liberal Sufi Islam, describing Shariah "-as God's prescriptions derived from the Qur'an and the Prophet Muhammad's example - to guide acts of worship or 'ibâdât and social behavior or mu'âmalât' (Hill, 2013, p. 99). So, the religious texts were to guide both the act of worship as well as the social life; not just a rigid exercise of the laws without being in touch or not having human feelings.

On the other hand, Yusuf al-Qaradawi, one of the major voices among al-Azhar graduates adopts a liberal (wasati) approach to religious law (Shavit p. 417), trying to address the challenges the Muslim minorities face in the West although strongly challenged by the Saudi Arabia salafi conservatives. Maher discusses the Salafi in details (2016). Shavit writes:

The wasati approach ... presents two objectives: making the lives of Muslim minorities easier in order to preserve their Islamic identity, and endorsing efforts to Islamize the West. To promote these objectives wasatis emphasize a systematic search in all four religio-legal schools and beyond them and the liberal application of maslaha (public or individual interest). Some of the results achieved by this methodology demonstrate the potential of maslaha to revise any religious law relating to mucãmalát (social transactions). (Shavit, 2012, p. 418).

Shavit cites Yusuf Al-Qaradawi defining fiqh al-aqalliyyat al-muslima as the fiqh on Muslims in majority non-Muslim societies like the West. This position gives Muslims the opportunity to adapt to other cultures and assimilate if they choose to. Shavit further traces the idea of this kind of fiqh to the $9^{\text {th }}$ century CE debates on whether it was ideal to reside in non-Muslim countries or areas. However, Shavit suggests the $10^{\text {th }}$ and $11^{\text {th }}$ centuries debates were on how Muslim resident minorities of a country possibly had their faith and practices weakened thereby giving the non-Muslims the upper hand against the Muslims. Migrating to non-Muslim areas will be legitimate for Muslims, they suggested, only if they have no other alternatives and are able to practice Islam in their new location (p. 417). Further studies show how Muslims' residence became legitimized in the following centuries as they had the freedom to practice their religion, (Shavit, 2012, p. 418). The rule of social life (muamalat) thus paid off for Muslims not to be rigid as they interact with other people in a general social context: 
The wasati approach encourages Muslims to create a presence in the West and modifies some religious laws in response to the special condition of living as a minority; the salafi approach permits residence in the West on more restrictive terms, and rejects the permissibility of adjusting religious laws to accommodate the minority condition. While the two approaches are grounded in revivalist, triumphalist justifications, the wasati approach allows for a large measure of interaction with and integration into Western societies, while the salafi approach promotes segregation from non-Muslim majorities. (Shavit, 2012, p. 418).

The wasati approach here is like the Yorùbá Muslim's way of life among their non-Muslim neighbours and extended families, not necessarily because they are in the minority, but it seems to have become a way of life, all other things being equal (reciprocating peace gesture).

So, in this paper, one may ask: how much freedom non-Muslims would have when Kyidà-Doruuri (Q-M-D) gives way to a full Shar'iah in their community? This is important, one, for a thick description study, and two, as it is hoped that the harmony among the Yorùbá will continue regardless of how and when more aspects of the Shari'ah begin to unfold among the land.

Lateef suggests that only a few places such as Mecca currently practise a full Shari'ah, where everybody must comply with the strict Islamic religious rules to the letter. This suggests that the harmony enjoyed by the Christian and Muslim Yorùbá is expected to last as they continue to practise tolerance in the context of Q-M-D. In the same way, it has been suggested that there has been harmony among the Yorùbá Christians and Muslims since the 1800s, during the Samuel Ajayi Crowther era (Cole, 2004; Law, 1991). It is attentiongrabbing, therefore, that over two centuries, the Yorùbá have been identified to be tolerant as far as ChristianMuslim relations are concerned and are accommodated among their indigenous religion and culture. The Yorùbá have avoided most external aggressions, intolerance, and violent ideologies, all of which remain alien to the Yorùbá family. The unity is seen to be weakened in some places (FGD2) due to some intolerant ideologies foreign to the Yoruba and the recent controversies over the use of the hijab on top of the school uniform in some Christian established mission schools.

Many Yorùbá have decided not to quarrel with their cousins, as indicated in FGD1. There is a likelihood that such harmony will continue, as revealed in these research findings regarding the use of Kidà-Doruuri (Q-MD). There, Muslims restrain the use of a full shari'ah, whenever it would make life unnecessarily difficult as both genders riding on the same motorcycle and would not hurt non-Muslim neighbours or fight their cousin because of religious differences, the position strengthened in the FGD1, mb - FI and Mic - FI.

The committed Yorùbá Christians also seek to work in peace with everyone and show love to their Muslim and other neighbours or extended family members as a requirement for their access to the Kingdom of God.[6] They both want to avoid provocative sermons (or waasi) and seek understanding when their members convert to another religion - either way. In that light, Wlé at the FGD3 argues that the occasional violent conflicts among the Yorùbá are mostly politically sponsored, as 'No religion as understood and practised by the contemporary Yorùbá Christians and Muslims really allows you to kill in its name'. This claim suggests the cultural weight given to the interpretations of religion and religious texts as significant to the peace culture in the Yorùbá community.

Ldun in Sptrí (FI) cites the harmony between the Yorùbá Christians and Muslims in relation to their communal lifestyle. Similarly, Wlé and Ifá (2016) regard most violent conflicts as originating from manipulation and, where politics is involved, may have economic undertones. This supports the Peaceful Societies (PS) idea of avoiding greed and their use of simple local leadership style in their communities rather than modern political strategies considered to be complicated.

Back to the useful idea of promoting peace among the Yorùbá, the idea of Kidà or the rule of practising the shari'ah as far as the circumstances allow whilst being tolerant of those who do not hold the same faith, religion or traditions is a welcome idea. Kidà - moderated Islam, which the author terms Al-Qaida- 
Muamalat-Darar (Q-M-D) is being identified and emulated rather than being enforced. This is a practice among the Yorùbá as they interact over the past two centuries.[7]

A similar idea is reported among the Senegalese Sufi Muslims and their local Christian community, although the term Kidà-Doruuri (Q-M-D) is not used by the scholars involved in the Senegal research. Furthermore, a Senegalese Muslim mayor gave a painting of Jesus's crucifixion as a gift to a Catholic priest, to the amazement of the priest (UguccioniI, 2018) since most Muslims place a greater focus on Mary rather than the cross or the crucifixion and resurrection of Jesus. This gesture is fascinating, more so to a Christian missionary, reflecting an incredible understanding of Christian-Muslim relations, a step beyond tolerance into accommodating others. The root of this theory is in the interpretation (hermeneutics) of religion against a background of love and hospitality, situated in the culture of the host or the local community. To people in this category, knowingly or unknowingly, the concept of 'good' in the local culture moderates the interpretations of their religions. This, however, does not mean that there is no possibility of threats to the peace of the community concerned, but the continuing ability to reject violence and maintain harmony remains the strength of the communities where Kidà-Doruuri (Q-M-D) is identified and/or practised.

A quote from Mahmoud \& Makoond comes to mind:

Sustaining peace constitutes a paradigm shift in how we think about peace and how we address conflict. As a process and a goal, building sustainable peace is not the burden of outsiders. Even under the direst of circumstances, external interventions should endeavor to build on what people know and what they have. Societies that have developed national infrastructures for peace offer valuable lessons for this eminently internal enterprise. More needs to be done to demystify the concept at the national and global levels. (Mahmoud and Makoond, 2017, p. 5).

One of the points from the above quote significant to mention is 'build[ing] on what people know and what they have'. The Yoruba's way of accommodating others is seen in their search for and utilizing concepts that appeal to peacefulness regardless of what is obtainable in other cultures like leaning more on the social interpretation of their religion and culture as seen in the use of Q-M-D. This has to do with the need for the sustainability of peace that is not alien to their community and the need to extend such to their neighbours.

\subsection{Religious Leadership}

Leadership plays a major role in the development of a group or nation as much as it does in the moulding of a community. On the role of religious leaders, Adé in the interview (FI) suggests that just as Christians have the order in their appointment of ministers to their churches, so also many Yorùbá community mosques appoint their Imams. This complements Ldun's idea that religious leaders should undergo training before embarking on leadership roles (FI). Such years of training might have some positive influences on the leaders' hermeneutical predispositions for or against peacefulness. The Islamic Kidà-Doruuri and Christian love for neighbours is seen in how leaders and parents handle sensitive religious matters. Adé discusses a scenario in which some Muslim fathers warned their Sunni youth to stay out of trouble when some militant youth wanted to take over a mosque programme. The peaceful Sunni boys obeyed their fathers by boycotting the meeting. This is an example of intra-faith relations. The leader of the 'rebellion' fell while climbing the stage and died, according to Adé. The Yorùbá Muslim leaders called the death of the rebellion 'nemesis' (san nké); likewise, some Christians and Gideon consider the deaths of the perpetrators of violence on some Christians to be God's judgement. These both point to Wlé's claim that the Yorùbá believe in the enacting of God's vengeance on earth and the final judgement after death (or heaven). To corroborate Wlé's suggestion, the author cites Olupna suggesting that the Yorùbá religion punishes offenders faster than in Islam and Christianity:

There is a strong belief even among the educated Yorùbá that while it takes the God of the Bible or Qur'an a long time to act against sinners and offenders (as both Gods suspend sentences 
pending a sinner's repentance), the judgement of Ogun is swift and certain. (1993, p. 251).

From the above, however, all the three religions look forward to God's intervention in their crisis time immediately or later and want to be blameless during God's judgement. Similarly, Adé cites an example from an Islamic community:

Those with extreme religious commitment often initiate conflict but do not often materialise. An Islamic militant group refused to perform the parents' funeral. On one occasion, the deceased had six children, two of the children belonging to this extremist group while the remaining four children told the other two extremists to stay clear. The ceremony was done without violence.

Adé's argument shows that Islam, as practiced among the Yorùbá, is not a single strand just as there are many denominations among Christians. There are patterns accepted in Islam relevant to the Yorùbá culture and others considered aggressive and thus rejected by the mainstream Yorùbá Muslim community. Adé's example might not be known to Lateef, who claims that any Yorùbá who is violent towards his neighbour is either intoxicated or has not lived among the Yorùbá from childhood to learn the peaceful culture of mluabí. Or Adé may be unaware whether the perpetrators of violence he cited had lived abroad. Nevertheless, the culture or teaching that dominates the community determines the flow of peace or violence in such a community. The crucial things are the leadership and the contents of their teaching or sermon.

One of the strengths the Yorùbá display is in the leadership and ability to detect conflict or division and stop it before it escalates. Adé, Odù, Diran, Ayo and Akan suggest this in the interview (FI) and Wlé, in FGD3. The harmonious relationships in Yorùbáland between different religious groups are thus sustained by the community and the religious leaders. A change in the leaders' beliefs or interests can have serious implications for the community's peaceful engagement. Thus, responsible Islamic, Christian, and indigenous religious leaders in Yorùbáland are often privileged of knowing when potential conflicts are approaching and warn their wards to be careful of violent groups and ideologies.

As seen among the Yorùbá, the Senegalese Christian minority and Muslim (Sufi) majority have peacefully co-existed for many years (UguccioniI 2018). Senegal is a country, while Yorùbá is a 'language group' (often referred to as Yorùbá nation). Senegal has many languages, while Yorùbá is just one language with many dialects. The Senegalese population is 5\% Christian and 95\% Sufi Muslim, while the Yorùbá religions make up is thought to constitute approximately equal numbers of Christians (evangelical in larger proportion) and Muslims. The percentage of the indigenous worshippers is not very certain. A thorough examination of the places of worship and the attendance at each worship time, however, could show that those identifying as Christians are more than the Muslim population, then followed by the indigenous worshippers in Yorùbáland. With the assumed 50:50 representation for Christians and Muslims, crises and conflicts are managed with a religious and ethnic undertone and for religious and ethical purposes. The Yorùbá do resort to the mluabi attributes to restrain themselves in times of dispute and conflict.

On teaching and leadership, Ldun suggests that loving one another and instructing the youth to avoid bad company associated with gangsterism are necessities for a harmonious community. Therefore, being religiously conscious people with a goal of pleasing God, lrun or Allah, the Yorùbá often restrain from violence, especially when they are not under the influence of alcohol (or intoxicant) as Lateef reiterated, or an outside influence, as in the case of Gideon's narrative (FI). The clerics' teachings embedded in their ethical values help keep the peace. The ethics of peace are what Wlé describes as 'providing domestic answers to the Yorùbá domestic problems by using the Yorùbá value (yardstick) to understand the Yorùbá way of life' (FGD3). Lateef underscores the use of internal settlement to resolve conflict (FI). This is seen in the Yorùbá's promptness in resolving disputes, delay, or avoidance of pressing charges in court for non-criminal cases, with the saying, akì ti kóotù dé sre meaning it is difficult to retain a close friendship after embarking on a court case. Leadership and the teaching that predominantly influence the life and thoughts of the society at the same time control their peacefulness. 
This Yoruba peaceful disposition has been abused by foreign Fulani herders ravaging the Yoruba forests and villagers in recent time kidnapping for ransom or murder, and destruction of their farms. The provocation has led to the call for the Yoruba self-determination to form an independent nation out of Nigeria to be able to preserve their life, values, and civilization.

\section{Conclusion}

The interpretations and understanding of religions spearheaded by leaders are ways of de-escalating conflict and maintaining the peace. An example is the idea of Kidà-Doruuri (Q-M-D), the act of practicing religion (or shari'ah in this case) as much as the situation allows among the Yorùbá Muslims and the correspondent expression of care among the Yorùbá Christians. With a religion regulated by social life (not wanting to hurt self and neighbours) and the Christian love and holiness ethics in place, the peace culture among the Yorùbá is expected to last. This buttresses Mahmoud and Makoond's argument about society that have developed peace structure having something to offer peace debate.

The Yorùbá religious communities pursue the virtues approved by their religions, which in turn strengthen the harmony in their culture. In an ideal situation, therefore, the Yorùbá preserve their peace through the established Yorùbá culture, living as family and good neighbours. When these features crumble, as seen on some occasions, violence and rancour occur. Peace is possible when nurtured by the parties involved through the interpretation of religions suitable for peacefulness within a relevant cultural context and coordinated by responsible leaders.

\section{Reference}

Ade. (2016). Interview, In: Olayinka, A.S. Research Data.

Adesina and Gbenro (2010) 'Muslim Students Paralyse University Ibadan Over Student Preacher PMNews Lagos'. Available at: https://www.thenigerianvoice.com/news/33130/that-christian-studentin-university-of-ibadan.html.

Akan. (2016). Interview, In: Olayinka, A.S. Research Data.

Akinjogbin, I. A. (1966) 'The Oyo Empire in the 18th Century - A Reassessment', Journal of the Historical Society of Nigeria, 3(3), pp. 449-460.

Arabic-English-Dictionary $\quad<\mathrm{p} \quad$ class="MsoNormalCxSpFirst" $\quad$ style="margin-top:0cm;mso-addspace:auto;line-height:107\%;mso-layout-grid-align:auto;text-autospace:ideograph-numeric ideographother">Reverso-Dictionary', q'd@. Online: https://dictionary.reverso.net/arabic-english/ $\% \mathrm{D} 9 \% 82 \% \mathrm{D} 8 \% \mathrm{~A} 7 \% \mathrm{D} 8 \% \mathrm{~B} 9 \% \mathrm{D} 8 \% \mathrm{AF} \% \mathrm{D} 8 \% \mathrm{~A}$.

Ayo. (2016). Interview, In: Olayinka, A.S. Research Data.

Bolanle and Taibatu. (2016). Interview, In: Olayinka, A.S. Research Data.

Buchanan, I. (2018). thick description. In: Oxford University Press.

Cole, G. R. (2004). 'Liberated Slaves and Islam in Nineteenth-Century West Africa', in Falola, T. and Childs, M.D. (eds.) The Yoruba Diaspora in the Atlantic World. Bloomington: Indiana University Press, pp. 383ff.

'Darar'. Oxford-Islamic-Studies-Online (n.d.), Oxford, UK: Oxford University Press. 
Diji, O. (2012) Christian life in northern Nigeria. BBC NEWS: Africa: http://www.bbc.co.uk/news/ world-africa-20141305.

Diran. (2016). Interview, In: Olayinka, A.S. Research Data.

Feyisetan, B. and Pebley, A. R. (1989) 'Premarital Sexuality in Urban Nigeria', Studies in Family Planning, 20(6), pp. 343-354.

FGD1 (2016) Focus Group Discussion FGD1, Ogbomoso, Nigeria. Research Data.

FGD2 (2016) Focus Group Discussion FGD2, Sepeteri, Nigeria. Research Data.

FGD3 (2016) Focus Group Discussion FGD3, Ilorin, Nigeria. Research Data.

Freeman, M. (2014). The Hermeneutical Aesthetics of Thick Description. Qualitative Inquiry, 20(6), 827-833. https://doi.org/10.1177/1077800414530267

Geertz, C. (1994). Thick Description: Toward an Interpretive Theory of Culture. Readings in the philosophy of social science, 213-231.

Gideon 2016. Interview at Sepeteri, Oyo State. In: Olayinka, A.S. Research Data.

Hellmich, N. J. D.-B. Qa'ida, al. Oxford, UK: Oxford University Press.

Hill, J. (2013) Sovereign Islam in a Secular State: Hidden Knowledge and Sufi Governance Among "Taalibe Baay". Columbia University Press.

Ifa. (2016) FGD3: The focus group discussion 3 in Ilorin, Kwara State. Research Data.

Kazah-Toure, T. (2003) Ethno-religious conflicts in Kaduna State. Kaduna, Nigeria: Human Rights Monitor.

Lateef. (2016). Interview of an Imam who also had Western Education and a Christian brother. In: Olayinka, A.S. Research Data.

Lateju, F. T. (2012) 'Religious Conflict and Peace Building Initiatives in a Multi-Religious Nigeria', in Lateju, F.T., Samwini, N. and Ayegboyin, D. (eds.) Christian-Muslim Relations in West Africa. Ibadan: West African Association of Theological Institutions WAATI.

Law, R. (1991) The y empire, c.1600-c.1836: A West African imperialism in the era of the Atlantic slave trade. Modern Revivals in History Y Aldershot: Aldershot: Gregg Revivals.

Ldun. (2016). Interview of a Muslim retired teacher in Sepeteri, Oyo State. In: Olayinka, A.S. Research Data.

Maher, S. (2016). Salafi-Jihadism: The history of an idea. Oxford University Press.

Mahmoud, Y. and Makoond, A. (2017) Sustaining Peace What Does It Mean in Practice? International Peace Institute. Available at: www.jstor.org/stable/resrep09504 (Accessed: 2020/05/14/).

Maku. (2016). Interview of an Imam without the Western Education. In: Olayinka, A.S. Research Data.

Mavani, H. (2011) 'The case for secularity in Islam', The Journal of Islamic Law \& Culture, 13(1), pp. 34.

Merriam-Webster. (n.d.). Hermeneutic. In Merriam-Webster.com dictionary. Retrieved April 30, 2021, from https://www.merriam-webster.com/dictionary/hermeneutic.

Merriam-Webster. (n.d.). Hermeneutical. In Merriam-Webster.com dictionary. Retrieved April 30, 2021, from https://www.merriam-webster.com/dictionary/hermeneutical.

Mic. (2016). Interview in Mixed/Interfaith Marriage Context. In: Olayinka, A.S. Research Data.

'Muamalat', Oxford Islamic Studies Online'. Oxford, UK: Oxford University Press.

New-King-James-Version (2006) The Holy Bible Giant Print Edition. Nashville: Thomas Nelson Since 1798. 
Odu. (2016). Interview, In: Olayinka, A.S. Research Data.

Okoye, G. O. (2014). Proclivity to Genocide: Northern Nigeria Ethno-Religious Conflict, 1966 to Present. London: Lexington Books.

Olupna, J. K. (1993). 'The Study of Yoruba Religious Tradition in Historical Perspective', Numen, 40(3), pp. 240-273.

Omobo. (2016). Interview in Mixed/Interfaith Marriage Context. In: Olayinka, A.S. Research Data.

Ope. (2016). FGD3: The focus group discussion number 3 in Ilorin, Kwara State. Research Data.

Peel, J. (2016). 'Christianity, Islam, and Orisa-Religion: Three Traditions in Comparison and Interaction', Jstor, Available: University of California Press.

'Qiblah'. Oxford-Islamic-Studies-Online (n.d.). Oxford: Oxford University Press.

'Qur'an'. (2000). The Meaning of the Glorious Qur'an: An Explanatory Translation, Mohammad Marmaduke Pickthall. Birmingham: Islamic Mission Dawah Centre Birmingham (UK). $2^{\text {nd }}$ Print.

Ronke. (2016). Focus Group Discussion FGD1c, Ogbomoso, Nigeria. Research Data.

Sango. (2016). Focus Group Discussion FGD1, Ogbomoso, Nigeria. Research Data.

Senegal-n.a. (2009). Senegal: Conversation in a University', Regions and Themes: Africa. https://insideislam.wisc.edu/regions-and-themes/africa/senegal-conversation-in-a-university/. Available at: https://insideislam.wisc.edu/regions-and-themes/africa/senegal-conversation-in-a-university/.

Senegal-UW-Collaboration. (2009). 'Senegal: Model for Interfaith Peace', Regions and Themes: Africa. Inside Islam: Dialogue \& Debates. Challenging Misconceptions Illuminating Diversity. A Collaboration of the UW-Madison's National Resource Centres and WPR's Here on Earth: Radio Without Borders.: University of Wisconsin-Madison. Available at: https://insideislam.wisc.edu/regions-and-themes/africa/ senegal -model-for-interfaith-peace/.

Shavit, U. (2012). 'The Wasatī and Salafī Approaches to the Religious Law of Muslim Minorities', Islamic Law and Society, 19(4), pp. 416-457.

Taiwo, F. 2020. Kyídà: Telephone Interview location at Ogbomoso, Nigeria. In: Olayinka, A.S. Research Data.

Tayob, A. (2012). 'Politics and Islamization in African Public Spheres', Islamic Africa, 3(2), pp. 139-168.

UguccioniI, C. (2018). Senegal, where Christians and Muslims live together in peace: Herald Malaysia Online. Available at: http://www.heraldmalaysia.com/news/senegal-where-christians-and-muslims-live-togetherin-peace $/ 40619 / 1$.

Wisconsin-n.a. (2009). Senegal: An Imam in Saint Louis', Regions and Themes:Africa: https://insideislam.wisc.edu/regions-and-themes/africa/senegal-an-imam-in-saint-louis/.

Wlé. (2016). FGD3: The focus group discussion number 3 in Ilorin, Kwara State. Research Data.

\section{NOTES}

[1] The comprehensive data cannot be displayed here due to space but are available in the dissertation.

[2] Be it Christians, Muslims, and Indigenous practitioners. 
[3] See the Holy Bible: - Genesis 25, 1 Samuel 1; 2 Samuel 3: 1-5; 1 Samuel 25; 1 King 11, Luke 1.

[4] Mavani citing Tariq Ramadan, Radical Reform: Islamic Ethics and Liberation (Oxford: Oxford University Press, 2009) p. 20.

[5] Mavani with reference to "Actions are judged by the intentions" (innama al-a'mal bi al-nivvat); Muhammad b. Isma'il al-Bukhari, Sahih Bukhari (Dar al-fikr, Beirut 1980) 1, 2.

[6] See Hebrews 12: 14

[7] See the reference to Crowther's interaction with Muslims and vice versa in Cole (Ibid) and Law (Ibid) 